\title{
The Meaning of Charity in Locke's Political Thought
}

\section{Robert Lamb and Benjamin Thompson ${ }^{1}$}

\begin{abstract}
The recent 'religious turn' within Locke scholarship has stressed the need to understand his theological commitments when approaching his political thought. One area of interpretation that has been completely transformed by this heightened sensitivity to the religious roots of Locke's thought is his account of property ownership which, it is claimed, contains a 'right to charity' - a subsistence entitlement that trumps established ownership rights. However, this increasingly accepted interpretive claim has been made without significant attention to the way in which charity is deployed throughout Locke's writing. The aim of this article is to try and get to grips with Locke's various usages of the term and determine whether the concept he deploys is a consistent one. After discussion of the uncertain role charity plays in his account of property, we examine how it is defined in the Essay Concerning Human Understanding, and then turn to the crucial position it occupies in his theological corpus. Though Locke's understanding of charity seems fraught with ambiguities, the reason for these ambiguities relate to his configuration of charity as a disposition rather than a mere act, a configuration linked inextricably to his account of toleration.
\end{abstract}


There has been a widely acknowledged 'religious turn' in recent interpretive accounts of Locke's political thought. ${ }^{2}$ An appreciation of the deep theological underpinnings of his moral and political works - initially emphasised in the seminal work of John Dunn $^{3}$ - has become increasingly regarded as necessary to their understanding. The importance of this appreciation has been underlined more recently in Jeremy Waldron's innovative and provocative analysis of the way in which Locke's religious commitments substantively inform his egalitarian philosophical premises and normative prescriptions. ${ }^{4}$ The work of Dunn, Waldron and others has revealed numerous problems with previously dominant Straussian and Marxist readings of Locke's political thought; readings that either ignored or explained away the significance of his theological commitments. What the 'religious turn' has revealed, above all, are the problems with regarding Locke as the philosophical father of liberal politics, a view that sits uncomfortably with much of his thought.

One area of interpretation that has been completely transformed by this heightened sensitivity to the religious roots of Locke's thought is his well-known and still influential account of property ownership put forward in the Two Treatises. Long-established interpretations — often Marxist in origin — that viewed Locke's theory as an ideological justification for 'unlimited capitalist appropriation', the personification of 'possessive individualism', have been thoroughly discredited, replaced by alternative readings that stress the conditions he attaches to property ownership; conditions with a markedly religious character. ${ }^{5}$ In fact, it has become increasingly accepted that one of the most crucial conditions that Locke places on ownership is a universal and unconditional entitlement to subsistence provisions, a 
right that actually trumps established rights of justly owned private property and that derives from his Christian theology.

The nature of this entitlement is, however, rather ambiguous, not only because it does not actually appear in the account of property in chapter V of the Second Treatise, but also because when it is invoked, it is described as a 'right to charity'. Within contemporary liberal accounts of political morality, charity is customarily regarded as a voluntary transfer from one agent in a position of relative comfort to another in a position of relative indigence. ${ }^{6}$ Charity is certainly a moral obligation, but, crucially, it is an imperfect obligation, a supererogatory action that individuals can legitimately opt out of without suffering any significant opprobrium. Acts of charity are, by their very nature, legitimately avoidable. When such acts do take place, they are in recognition of imperfect duties, distinguishable from perfect duties; in liberal accounts of political morality, matters of charity are defined by what they are not, matters of justice.

A. John Simmons rightly points out that Locke's works are 'liberally peppered' with references to charity and that any denial of this can be dismissed as 'odd'. ${ }^{7}$ Yet Simmons and other recent Locke scholars deny that it is liberally peppered; that is to say, they reject the claim that the understanding of charity that Locke deploys is the liberal one of supererogatory moral action but rather a quite different Thomistic understanding. However, this now widely accepted interpretive claim about the Thomistic nature of Lockean charity has been made without sufficient attention to the way in which charity is deployed throughout his writing. Thus, the aim of this article is to try and get to grips with Locke's various usages of charity and determine whether the concept that he deploys is a consistent one and then, on this basis, address its moral and political meaning. ${ }^{8} \mathrm{We}$ begin by identifying the 
ambiguous role occupied by charity in Locke's account of property ownership and subsistence rights in the Two Treatises and in other relevant writings on politics and economics. After discussion of this, we move on to examine how Locke defines charity in the Essay Concerning Human Understanding, before turning to the crucial position it occupies in his theological corpus. We argue that whilst Locke's understanding of charity and its relationship with justice in his political work seems ultimately fraught with ambiguities, proper attention to the breadth of his corpus reveals these ambiguities to be related to his acceptance and configuration of charity as a disposition rather than a mere act; a configuration that is inextricably linked to his account of toleration.

\section{II}

Locke's account of property ownership begins with an original community of goods: he claims that, initially, God bequeathed the world 'to Mankind in common' and granted no individual an exclusive right of ownership. ${ }^{9}$ The way that private property rights emerge from this community of goods is through individual applications of labour on natural resources. ${ }^{10}$ The reason that labour is capable of generating such exclusive rights relates to a fundamental moral principle underpinning Locke's thought, the duty to ensure their own preservation that individuals owe to God: 'every one... is bound to preserve himself, and not to quit his Station wilfully'. ${ }^{11}$ It is this crucial moral obligation of self-preservation that gives the activity of labour real moral force. ${ }^{12}$ 'It cannot be supposed', Locke explains, that God intended the world to 'remain common and uncultivated', since it was given for human 'benefit'. Therefore, he suggests that when God 'gave the World in common to all Mankind, [he] commanded Man...to labour, and the penury of his Condition required it of 
him'. ${ }^{14}$ Importantly, Locke does not expect every individual to obey God's 'command' to labour, despite the fact that he thinks that they, morally speaking, should obey it. Indeed, he draws an explicit distinction between the 'Industrial and Rational' who do obey the labour command and the 'Quarrelsome and Contentious' who do not and whose subsequently fraudulent claims to the property of others represent mere 'Fancy and Covetousness'. ${ }^{15}$ This differential tendency to labour is further reflected in Locke's view of how distributive shares ought to unfold: 'different degrees of Industry', he suggests, are 'apt to give Men Possessions in different Proportions'. ${ }^{16}$

Locke is clear that when individuals acquire private property rights through labour, these rights 'exclude...the common rights of others' ${ }^{17}$ But what happens to those who simply fail to labour and, as a result, fall into a state of hopeless indigence whilst the world's property is appropriated? In libertarian accounts of private property rights, such as that advanced by Robert Nozick, the story would seem to end here. ${ }^{18}$ According to such theories, individuals are not thought to have an inviolable 'right to life' that would require a transfer of resources from a property-owner to a person under threat of starvation. This, however, is where Locke and libertarianism would seem obviously to part company, since he clearly is committed to human preservation; that is, after all, what provides labour (and therefore property rights) with moral justification in the first place.

It is then unsurprising that Locke does actually suggest that when an individual's survival is not itself in question, that agent ought to do 'as much as he can' to 'preserve the rest of Mankind'. ${ }^{19}$ This clearly has the potential to transform Locke's theory of property, since it appears to show that individuals have positive obligations to others in addition to their direct duty to God, to secure their own 
preservation through labour. There are, however, very few points in the Second Treatise at which Locke elaborates on this moral imperative to assist others. Even in the passage in which the imperative appears, our obligations to others are presented in a negative sense: thus, individuals

...may not unless it be to do Justice on an Offender, take away, or impair the life, or what tends to the Preservation of the Life, the Liberty, Health, Limb or Goods of another. ${ }^{20}$

This passage suggests that agents are obliged to refrain from threatening the life of another, rather than having any positive duty to preserve that life. The idea that individuals have substantial duties to others is repeated (or at least implied) elsewhere in the Second Treatise. On no less than three separate occasions, a 'Fundamental Law of Nature and Government' is identified as one that ensures that 'as much as may be, all...Members of...Society are to be preserved ${ }^{21}$ Yet the precise meaning of this aspect of the law of nature and its corresponding impact on property ownership remains unclear. It is certainly insufficient evidence on which to ground a robust subsistence claim that would trump established property ownership—especially with the ambiguous 'as much as may be' clause.

There are other points within the Second Treatise where Locke appears to detail a subsistence right, but none are unambiguous. One notable example concerns children whom, he claims, have a 'Title to their Father's Estate for their Subsistence ${ }^{22}$ - a title that should be respected even when their father has been defeated in a just war. In fact, in the First Treatise, Locke suggests that children are entitled 'not only to a bare Subsistence but to the conveniences and comforts of Life'. ${ }^{23}$ However, despite the inviolable nature of this right, a very specific justification is offered for its existence, one that undermines any inference made from it to a wider concern with subsistence. 'Children', he explains, are entitled to a 
subsistence right because 'being by the course of Nature, born weak, [they are] unable to provide for themselves'. ${ }^{24}$ The implication seems to be that were children ableor, were children 'adults' - there would be no justification for subsistence provisions. This example does not, then, vindicate the case that Locke guarantees subsistence for the needy, because it is not that they are needy, but that they are children that is of moral relevance. ${ }^{25}$

There is, then, no conclusive evidence of a substantial subsistence right anywhere in the Second Treatise. But, as a number of commentators have pointed out, there is a passage in the First Treatise (I: 42), which does appear to reveal such a right. Here Locke declares that:

...we know that God hath not left one Man so to the Mercy of another, that he may starve him if he please: God the Lord and Father of all, has given no one of his Children such a Property, in his peculiar Portion of the things of this World, but that he has given his needy Brother a right to the Surplusage of his Goods; so that it cannot justly be denyed him, when his pressing Wants call for it. And therefore no Man could ever have a just Power over the Life of another, by Right of property in Land or Possessions; since 'twould always be a Sin in any Man of Estate, to let his Brother perish for want of affording him Relief out of his Plenty. As Justice gives every Man a Title to the product of his honest Industry, and the fair acquisitions of his Ancestors descended to him; so Charity gives every Man a Title to so much out of another's Plenty, as will keep him from extream want, where he has no means to subsist otherwise. ${ }^{26}$

This is evidently an extremely important passage. Locke here seems to suggest that in any individual in desperate physical need has a right to the goods of any property owner, provided the owner has a surplus of those goods. A property owner cannot justly deny the appropriation of such a surplus of goods by a needy individual and this would seem to legitimate actions otherwise classifiable as theft. If passage I: 42 is taken seriously, Locke's claim seems to be that although some individuals are able to acquire rights to 'justice' through 'honest Industry' or inheritance, individuals always retain an equal and universal right to 'charity', a 'Title' to the surplus goods of 
another in circumstances of desperate need. But this passage is not only anomalous in the context of the Two Treatises, it is also itself fairly ambiguous. The distinction between 'justice' (the acquisition of property through either labour or inheritance) and 'charity' (the subsistence right) looks strange to the modern eye. This is because, as noted earlier, in modern liberal thought, charitable actions are supererogatory and therefore legitimately avoidable. How, then, can Locke defend a subsistence right that cannot 'justly' be denied whilst deploying the term 'charity' instead of 'justice' to classify this right?

\section{III}

Numerous Locke scholars would probably dismiss such a worry as essentially anachronistic: they would regard it as fundamentally mistaken to interpret Locke's deployment of the term 'charity' through the conceptual distinctions associated with contemporary liberal accounts of political morality. This is because the modern liberal conception of charity as supererogatory action was not given systematic expression until the eighteenth century by thinkers such as Adam Smith and the imputation of such an understanding to Locke is to make a basic historical error. Whilst considering the provision of alms to the needy, Smith contended that 'a beggar is an object of our charity and may be said to have a right to demand it — but when we use the word right in this way it is not in a proper but a metaphoricall sense'. ${ }^{27}$ In other words, the beggar has a right to our alms, but because it is only an imperfect right, there exists only an imperfect obligation and we can legitimately withhold assistance.

Most recent analysts of this area of Locke's thought seem to implicitly endorse such a charge of anachronism insofar as they assume I: 42 to reveal his brief rehearsal and approval of a medieval and early modern understanding of charity. James Tully, 
for example, views this passage as evidence of Locke's incorporation of a Thomistic understanding of charity in an attempt to respond to apparent defects in the natural law accounts of property advanced by Grotius and Pufendorf. Unlike Grotius who did not incorporate such a duty and unlike Pufendorf who embedded it in the wider context of property rights based on convention, a charitable obligation for Locke is described by Tully as a 'natural and positive duty' enshrined in natural law. ${ }^{28}$ Tully's $^{2}$ claim is that Locke's suggestion in this passage is that 'where no means are available for a man to provide for himself, the right to the means of subsistence applies directly to another person's goods....A proprietor who has more than enough to sustain himself is under a positive duty to sustain those who do not'. Thus, 'charity is a right on the part of the needy and a duty on the part of the wealthy'. ${ }^{29}$ Tully's claim is that the roots of this idea of charity are markedly Thomistic. ${ }^{30}$ Aquinas' understanding of charity, which Tully regards as 'strikingly similar' to that of Locke is expressed in the

\section{Summa theologiae:}

Things pertaining to human right cannot take anything away from natural right or Divine right. Now according to the natural order established by Divine providence, lower things are ordained for the purpose of supplying man's necessities. And so the division and appropriation of such things which proceeds from human law does not cancel out the fact that man's necessities must be supplied by means of those things. And so whatever anyone has in superabundance is due under the natural law to the poor for their succour. ${ }^{31}$

The point made here by Aquinas, that property rights over a 'superabundance' of goods do not hold when others are in desperate need, certainly does seem to mirror the view expressed by Locke in the First Treatise.

Other prominent scholars share Tully's characterisation of Locke's conception of charity as fundamentally distinct from the modern liberal alternative. In The Lockean Theory of Rights, A. John Simmons claims that it 'seems to approximate the 
familiar Thomistic conception' identified by Tully. ${ }^{32}$ Yet Simmons does identify the obvious difficulty that such a reading invites for Locke's account of property rights. For if the needy have rights of charity that permit them to appropriate the surplus goods of others, what does this mean for Locke's idea of justice as property ownership through 'honest industry'? Does one right (charity) actually trump the other (justice)? Though Simmons concludes that, in Locke's writing, the relationship between justice and charity is 'not very clear' ${ }^{33}$, he nevertheless regards the meaning of charity in Locke's thought as fundamentally distinct from the modern, liberal signification. More recently, in God, Locke, and Equality, Jeremy Waldron - whose disagreements with Tully on Lockean matters are considerable - advances a similar view. He describes Locke's idea of charity as 'a quite general doctrine', one expressed in language that is 'emphatically stronger than the liberal tradition' on the issue $^{34}$ and identifies it as a 'doctrine of rights generated by need', which he suggests, 'is set out as explicitly and as generally as could be'. ${ }^{35}$ Charity is here again understood as an obligation that is unavoidable; it is not a supererogatory action but one that individuals can actually be bound to by political authority. Indeed, Waldron insists that 'the fact that charity is regarded as a specifically Christian virtue is for Locke no reason for thinking that it is unenforceable' by government. ${ }^{36}$ According to him, at the very least, I: 42 defends 'the view that neither the rich nor civil society on their behalf is entitled to resist the poor when the poor attempt to seize their surplus goods for themselves'. 37

Nevertheless, there is some evidence within Locke's political thought that suggests his idea of charity is not as alien to that of modern liberalism as these commentators have claimed. As Waldron notes, within liberal political thought, charity is 'a paradigm of a moral duty that ought not to be enforced' ${ }^{38}$ Indeed, the 
failure of an individual to comply with a duty of charity is perfectly legitimate and would epitomise what Waldron has elsewhere identified as the 'right to do wrong' that defines modern liberalism; a right that can be witnessed in a variety of activities ranging from campaigning for a political candidate one knows to be racist to the refusal to tell someone the time at a bus stop. ${ }^{39}$ Within most liberal accounts of political morality, the refusal of charity is such a wrong that we have a right to and therefore an affluent individual has the right to tear to pieces all the money in her wallet rather than give it to a hungry beggar. According to Tully, Simmons, Waldron and others, Locke stands apart from modern liberalism in this regard. Indeed, for them, the entailment of Locke's argument is that it is the beggar (provided she is hungry enough) that holds a property right over the money, not the agent whose wallet it happens to be in at the time. As already noted, scholars like Tully maintain that Locke's idea of charity is Thomistic and non-modern, which implies that any attempts to examine him along liberal lines are doomed to collapse into anachronism.

Despite this, there is evidence that seems to indicate that under Lockean justice some uncharitable actions might be politically permitted without being morally endorsed. In other words, despite Locke's insistence that the obligations of the law of nature are the measure of personal as much as political morality ${ }^{40}$, there is evidence to suggest that he does recognise a 'right to do wrong'. One version of this right can be found in the Second Treatise itself. As discussed above, although individuals have a divine 'command' to labour because the activity satisfies the fundamental duty of human preservation, Locke expects there to be a number of 'Quarrelsome and Contentious' individuals who will shirk this duty. Individuals clearly have a legal right to be lazy even though Locke views laziness as morally wrong. The lazy 
certainly cannot claim title to the fruits of the labour of others, but their laziness will not be punished (unless, of course, they become a social nuisance).

There are other examples throughout his political works that would appear to lend credence to this interpretation. In his 1667 Essay on Toleration, in a discussion of the issue of begging, Locke identifies acts of charity as the recognition of duties that should (morally) be observed, but need not be (juridically) imposed. In fact, he goes much further than to merely define the failure to engage in charitable acts as a 'right to do wrong':

Even charity itself, which is certainly the great duty both of a man and a Christian, hath not yet, in its full latitude, a universal right to toleration; since there are some parts and instances of it which the magistrate hath absolutely forbidden, and that, for aught I could ever hear, without any offence to the tenderest consciences; for who doubts that to relieve with an alms the poor, though the beggars (if one sees them in want), is, if considered absolutely, a virtue and every particular man's duty; yet this is amongst us prohibited by a law and the rigour of a penalty, and yet nobody in this case complains of the violation of his conscience or the loss of his liberty. ${ }^{41}$

Here Locke begins with the suggestion that charity is 'the great duty both of a man and a Christian'. This is, however, immediately tempered: acts of charity do not have 'a universal right to toleration'. His conclusion is that there is nothing wrong with existing legal barriers that act to prevent the giving of alms to a needy beggar. Locke is clear that giving assistance to a needy beggar is a moral duty and a virtuous act, but is equally clear that government can for whatever reason, legitimately outlaw such acts.

It is important to note that this particular passage does not actually reveal anything about Locke's personal views on charity; whether he regards it as a perfect or imperfect moral obligation. Furthermore, this is early in his career, before he gravitated towards the radical Whig political views for which he is best known. And 
this particular passage was actually omitted from the final draft of the essay of which it is part, which might make it seem especially insignificant. But none of these factors diminishes the importance of this passage: not as evidence of Locke's view of the status of charitable obligations, but rather, as evidence of his recognition of a 'right to do wrong'. The very fact that he is able to identify charity as a moral obligation and yet also identify acts of charity as a legitimate subjects of government prohibition clearly indicates that the state need not impose moral behaviour - it is possible, for Locke, for individuals to hold a legal 'right' to do what is morally wrong. And, crucially, this would seem to undermine the claim that any imputation to Locke of a modern liberal conception of charity is necessarily anachronistic. Then, once the charge of anachronism is undermined, whether or not Locke's theory of property includes a subsistence right comes down to textual analysis of section I: 42 of the Two Treatises.

There is further ambiguous evidence about the nature of charity available in 'Venditio', Locke's unpublished essay on just market prices. Here he initially draws a firm distinction between justice and charity with his claim that

A man will not sell the same wheat this year under 10s per bushel which the last year he sold for $5 \mathrm{~s}$. This is no extortion... because it is this year the market price....If...he will sell his wheat only to the poor at this under rate, this indeed is charity but not what strict justice requires. ${ }^{42}$

Justice is here defined as selling at market price; charity by contrast, amounts to selling below it. What is crucial is that for Locke, charity is something supererogatory, an action that the merchant can legitimately avoid; strict justice does not require doing the poor a favour. And he repeats this again:

...what anyone has he may value at what rate he will and transgresses not against justice if he sells it at any price.... s say he transgresses not against justice; what he may do against charity is another case. ${ }^{43}$ 
The point again seems quite to be quite clear: matters of justice and charity are fundamentally distinct and differ in the kinds of obligation they generate. Charity appears to be a very important virtue for Locke, but the fact that an individual can-in charging however much we want for our goods - transgress charity without at the same time transgressing strict justice, suggests that it is not a perfect obligation but an imperfect one. Selling our goods at market price might be 'wrong', because it causes discomfort for the poor, who struggle to afford them, but it seems to be a 'wrong' that we have a 'right' to in Locke's eyes.

But even here there are ambiguities and although 'Venditio' clearly demonstrates Locke's belief that charity can be an imperfect moral obligation contrastable with perfect obligations of justice, the issue seems to shift when the preservation of human life is at stake. Indeed, towards the end of the essay, Locke declares that

...he that sells his corn in a town pressed with famine at the utmost rate he can get for it does no injustice against the common rule of traffic, yet if he carry it away unless they will give him more than they are able, or extorts so much from their present necessity as not to leave them the means of subsistence afterwards, he offends against the common rule of charity as a man and if they perish any of them by reason of his extortion is no doubt guilty of murder. ${ }^{44}$

Here, then, Locke suggests that the mere failure to act charitably is equivalent to murder. The question though is: is he guilty of murder as a Christian or as a citizen? Is the guilt part of a religious teleology, which would mean the individual would eventually answer to his or her Creator, or must the individual who transgresses charity instead answer to the magistrate? The law of nature would seem to indicate unequivocally that it is the latter and that the magistrate can intervene to punish the guilty party. But this is still not unambiguously so, as it remains unclear whether or not the corn-seller is under a positive duty to preserve lives or the negative alternative, 
whereby the corn must not be sold in an extortive manner but need not be sold at a just price, because it need not be sold at all and certainly cannot be appropriated by the needy without the consent of the owner.

\section{IV}

This apparent ambiguity in Locke's prescriptive political works demonstrates the need to understand his deployment of the term within the broader context of his religious writings. Taking Locke's religious thought and its context seriously, reveals an alternative conceptualisation of charity that is at once broader than but also able to explain its apparently uncertain use in his account of political justice. Instead of being merely applicable in relation to property transfers, obligatory or supererogatory, Locke's understanding of charity is dispositional, obligatory as a disposition, and frequently expounded in terms of toleration.

Turning to The Essay Concerning Human Understanding, important signs of Locke's thought on charity are present. In his discussion of charitable institutions such as hospitals and alms-houses, ${ }^{45}$ Locke appears to espouse a typical, liberal understanding of the term: voluntary property transfer in benefit of the afflicted. Put another way, charity is understood as supererogatory outward performance. But this does not put the issue to rest, for Locke is not referring to charity qua charity but to works of charity. This is only an instantiation of the concept and not a general definition of the term.

A crucial section elsewhere in the Essay, Book IV, Chapter 16, proves instructive. Here Locke confronts the sectarian zeal of "parties," which creates dangerous social divisions and ignores standards of rationality. ${ }^{46}$ The magnitude of $17^{\text {th }}$ century religious intolerance shows this is no idle concern. Neal Wood has 
described Locke's efforts in this part of the Essay at rescuing rationality from sectarian ignorance, further corroborating the significance of this topic. ${ }^{47}$

Intriguingly, Locke proposes an apparent form of toleration as a remedy. $\mathrm{He}$ writes:

It would, methinks, become all Men to maintain Peace, and the common Offices of Humanity, and Friendship, in the diversity of Opinions, since we cannot reasonably expect, that anyone should readily and obsequiously quit his own Opinion, and embrace ours with a blind resignation to an Authority, which the Understanding of Man acknowledges not. ${ }^{48}$

G. A. J. Rogers illuminates Locke's underpinning of this kind of toleration through what he calls the 'Argument from Ignorance'. ${ }^{49}$ The argument proceeds roughly as follows: if you cannot be absolutely certain of a proposition, you have no business in forcing others to accept what amounts to your opinion. This line of argument is clearly present in Locke's passage above. Since it is 'opinions' that are in conflict here, which are distinct from 'knowledge' in the Lockean epistemological lexicon, then we cannot force our opinions on others. Yet Locke's argument does not seem to conclude there.

In fact, typical discussions of Lockean toleration would seem to be unable to explain this section. Focusing on the negative sense of Lockean toleration, as above, would seem to be futile in the face of sects who are keenly intolerant. Instead Locke recommends what looks like positive affection in overcoming fanaticism and schism - positive toleration through peace, humanity, and friendship. Such mutual affability, is not merely overlooking differing opinions, but a positive duty, much like that Anthony Wilhelm has drawn out in his recent study on positive duty in Lockean toleration. ${ }^{50}$ By titling this section decisively, "The right use of it is mutual Charity and Forbearance," Locke implies that this benevolent disposition is integral to 
charity. Interestingly, Locke deploys the copular "is" in this passage. This means Locke may not be just describing an act of charity but equating charity with this disposition of positive toleration.

If Locke does indeed intend for charity to be identified with a form of toleration, then one might anticipate corresponding evidence of this position in Locke's explicit discussion of toleration. This is forthcoming in A letter Concerning Toleration $^{51}$ when Locke deploys in succession both charity and toleration as equivalent tests of true Christianity. Locke writes that toleration is, 'the chief distinguishing mark of the true church. ${ }^{52}$ And on charity:

For however some people boast of the antiquity of places and names, or of the splendor of their ritual; others of the reformation of their teaching, and all of the orthodoxy of their faith (for everyone is orthodox to himself): these claims, and others of this kind, are more likely to be signs of men striving for power and empire than signs of the church of Christ. If a man possesses all of these things, but lacks charity, meekness, and good will in general towards all mankind, even towards those who do not profess the Christian faith, he falls short of being a Christian himself. ${ }^{53}$

The upshot is that charity and benevolence with humility, like toleration, are the decisive qualities of the true Christian. Locke confirms the intermarriage of charity and toleration, but in so doing the role of this concept becomes more than an expedient against fanaticism. Specifically, charity, including the love of others even when they are in error, is transformed into the definitive Christian virtue.

This estimation of charity is not unique to the Letter on Toleration. Locke's central positioning of charity also appears in The Reasonableness of Christianity. In the 'Preface', Locke observes that charity itself is the spirit of the entire Gospel. ${ }^{54}$ Although a prefatory remark, the substance of Reasonableness seems to confirm this crucial, spiritual sense of charity. Locke describes Christ's judgement as one which distinguishes between the condemnable workers of iniquity and the redeemable who 
'fulfil the Law in acts of charity. ${ }^{55}$ This depiction seems peculiar at first because it is lodged within Locke's discussion of justification by faith. If Christians are justified by faith, not works, why would Christ judge according to acts of charity? Here Locke's doctrine of repentance proves educative. As it happens, true belief in Christ necessitates repentance, involving 'hearty sorrow' over, abhorrence of past and a forsaking of future sins. ${ }^{56}$ Hand in glove with this negative disposition towards sinning is a positive disposition toward moral behaviour. Locke presumes that Christians, as true believers in Christ, will endeavour to enter His kingdom and, thusly, 'working by love' obey his 'law and will. ${ }^{57}$ It is, then, the moral law which Christ reconfirms and pitches negatively against vainglory, violence, and impropriety and positively for 'Loving our Enemies; Doing good to those that hate us; Blessing those that Curse us; Praying for those that despighfully use us; Patience, and Meekness under Injuries; Forgiveness; Liberality; Compassion', and ultimately the 'Golden Rule' in Matthew VII. $12 .^{58}$ The majority of these traits are or entail some emotional standpoint. It seems strange to imagine patience, love, compassion, or forgiveness otherwise. Thus within repentance Locke identifies a disposition of benevolence and tolerance that matches a spiritual dread of sin. And, it is under this sense of repentance which the Christian is obligated to perform the moral law by which Christ judges works of charity. Charity then, prior to the works resulting from it, evidently bears some equivalence to this benevolent Christian disposition. For Locke, charity is, indeed, the spirit of the Gospel

Locke's depiction of charity is not without influential precedent. In fact, we can see that St. Paul utilises similar rhetoric in I Corinthians 13 in conveying an understanding of charity much like the one apparent in the Essay. Paul writes:

Though I speak with the tongues of men and of angels, and have not charity, I am become as sounding brass, or a tinkling cymbal. And 
though I have the gift of prophecy, and understand all mysteries, and all knowledge; and though I have all faith so that I could remove mountains, and have not charity, I am nothing. ${ }^{59}$

Lacking charity, Locke and Paul agree, that other goods and virtues are meaningless.

Even in context, St. Paul is dealing with schism in Corinth much as Locke is invoking charity in his attempts to remedy similar problems of sect and intolerance.

Substantively and stylistically, Locke's thought on charity seems to mirror St. Paul.

More substantively, when Locke, late in life, comments on Paul's I

Corinthians, his terminology overlaps that of his Essay and the Letter. For example, Paul's problem in Corinth is identified as "parties", ${ }^{60}$ the same term used in the Essay. As in the Essay, Locke perceives Paul's distinction between alms and charity, ${ }^{61}$ thereby repudiating the identification of property transfer with charity. Interestingly, Locke emphasizes the specifically dispositional sense of Pauline charity when he writes, "I will show you a more excellent way, viz. mutual good-will, affection and charity." 62 Locke uses good will, and affection to expound biblical charity, indicating a disposition, not an action. This interpretation reproduces the language of benevolence adduced in the Essay and his estimation of charity in the Letter. The point is not that Locke's charity might depend on St. Paul's (the time between the Essay and this commentary precludes that claim), but rather because his depiction of the Apostle's term matches his own, this lends credence to a dispositional interpretation of Lockean charity. In sum, Locke, in both his philosophical and theological corpus, seems to consistently define charity as a disposition of positive toleration and affability, placing this at the centre of Christianity, coequal even with justification by faith. 
In both verifying the likelihood of Lockean charity as a disposition and puzzling out its ramifications in regard to political activity and justice, it proves helpful to explore the way thinkers Locke read or esteemed developed notions of charity. Locke could have noticed the weight placed on charity in early Christian thought through his own study of scripture and, after 1680, patristic writings. ${ }^{63}$ This study would have occurred in time to influence Locke's mature work, and possibly even the Two Treatises, but there is not clear evidence which would suggest that Locke's study of such broad Christian sources would also have honed in on charity.

More compelling are a number of philosophers, moralists, and theologians in Locke's time with whom he had close interaction or positively recommended. These thinkers tended to be either the Cambridge-Platonists, or moderate Anglican members of the so called "latitudinarians." "64 Without making slippery claims about the group identity of latitudinarians and Cambridge Platonists or Locke's relation to these groups, all of the individuals examined below articulated conceptions of charity, love and the Christian spirit which show possible historical predication for Locke's views.

Before examining the substance of these thinkers' thought on charity, it is important to examine the kind of associations Locke had with them. The most obvious was Locke's close personal friendship with the Cambridge-Platonist Ralph Cudworth's daughter Damaris (Cudworth) Masham. Damaris herself was active in promoting her father's views and defended them in correspondence with Leibniz. ${ }^{65}$ Although speculative, it is no stretch of the imagination to presume that she could have discussed her father's work with Locke. Locke both corresponded with Cudworth's son Thomas and also seems to have known the Cudworth family before he left for Holland. ${ }^{66}$ All of this certainly shows the likelihood of Locke's intellectual 
familiarity with Cudworth's positions. As for Cudworth's published works, Locke started reading the True Intellectual System of the Universe by $1682 .{ }^{67}$

Locke's letters reveal explicit familiarity with several Cambridge Platonists. Amongst the most important of these is Locke's correspondence with Damaris Cudworth on the Select Discourses of John Smith. The letters focus on Locke's objections to Smith's Neoplatonic epistemology and on Damaris' attempts to convince Locke their positions are not so divergent as he imagines. ${ }^{68}$ In 1688 , Damaris corresponded with Locke again concerning the epistemology of the Cambridge Platonists and the question of innate ideas. ${ }^{69}$ Nearing the end of his life, Locke's letter to Richard King in August 1703, hails the sermons of Cambridge Platonist Benjamin Whichcote as a 'masterpiece' on the 'larger View of the Parts of Morality. ${ }^{, 70}$ Furthermore, Locke's epistolary recommendation of Whichcote was predated by thirty-five years, for Locke had known Whichcote and was a member of his congregation in London from $1668 .^{71}$ Locke's association with several members of the Cambridge Platonists is clear.

The thought of a number of moderate Anglican churchmen also appealed to Locke. Several latitudinarians are exemplary. Although the extent of Locke's identification with these figures' religious views is debated, there can be little doubt that Locke kept abreast of their work. ${ }^{72}$ In Locke's letters to Richard King, mentioned above, he recommends for the same purposes as Whichcote, Latitudinarians Isaac Barrow and John Tillotson. ${ }^{73}$ Interestingly, John Tillotson was a personal friend of Locke's. ${ }^{74}$ The letter to Richard King itself shows remarkable similarity to 'Some Thoughts Concerning Reading and Study for a Gentlemen' also published in 1703. In that text the liberal member of the Great Tew circle William Chillingworth is forcefully recommended for the right reasoning behind his speaking, 
not to mention 'anything of his argument. ${ }^{75}$ Locke's library tells a similar story. By the time of his death, more than one hundred works by contemporary Latitudinarians and 'many more' by Cambridge Platonists, including More and Cudworth, were shelved in Locke's collection. ${ }^{76}$ Suffice it to say that the evidence shows Locke's sustained interest in this dimension of contemporaneous English thought.

Unpacking the theology of these professors and divines shows there was precedent for Locke's understanding of charity. Most importantly, we want to draw attention to several key concepts integral to their understanding of charity which they develop, more or less consistently: first, the centrality of charity as a disposition to Christianity and justification; second, that charity as a disposition is obligatory; finally, the social ramifications of charity and the important parallel with toleration that these thinkers develop.

In their discussion of charity these Cambridge Platonists and liberal Anglicans consistently place it as a disposition at the centre of Christianity and the question of justification. One of Smith's major claims is that righteousness by faith is not about external performances in accordance with law, but concerns internal life, spiritual Godliness of the soul and the quickening spirit of the Gospel. ${ }^{77}$ Ultimately, "the righteousness of God" amounts to "a Christ-like Nature in a man's Soul, or Christ appearing in the Minds of men by the mighty power of his Divine Spirit... ."78 Righteousness by faith is not a type of knowledge, a promise, or an outward behaviour; rather, it is a disposition. Cudworth agrees. For him Christianity, while confluent with reason, cannot be coldly cognitive; it must contain a "quickening spirit" or vital life, for the New Law of the Gospel is itself vital. ${ }^{79}$ This vital spirit is a kind of laudatory passion or higher love, which Cudworth defines as charity, the "true intellectual instinct", superior love, and the love of honesty. ${ }^{80}$ Conceptually Smith 
and Cudworth's positions regarding charity and the essence of Christianity, match the claims Locke advanced about the dispositional nature of charity and its importance for Christianity.

Precisely because this type of charity is central to these thinkers' Christianity, it is qua disposition that charity is obligatory. Whichcote elaborates the Christian disposition in terms of moral duties. Whoever "professeth faith in the Gospel should live in universal Love and Good-will" - this is "absolutely' necessary in Whichcote's view. ${ }^{81}$ Whichcote holds that this attitude is called for by the New Testament more than anything else, remarking that "this cannot be said of very many Points of Divinity." ${ }^{\prime 2}$ Crucially, this kind of duty cannot be satisfied by outward performances, such as almsgiving:

For it is the choicest Piece of Charity; to make fair Interpretations, and to give Allowance; to make candid Constructions of Mens Actions; to afford civil and courteous Behavior; to be Conversant and Complacent. These Things tend to Love and Good-will among Men... ${ }^{83}$

Charity, Christian Love, is played out in these civil behaviours and attitudes. They represent duties both to think well of others and to interact with them beneficently. At the same time, these duties evince the social importance of charity, for all of them are conducive to civic peace. Crucially, and anticipating Locke's understanding, these duties can only be met through a charitable disposition.

A number of these thinkers clearly elucidate the role of this understanding of charity, like Locke, in terms of toleration. Henry More, Whichcote, and Chillingworth repudiate religious intolerance, worrying that it masks a deeper problem of egotistical love. For More, excessive, singular concern for religious doctrine destroys inward godliness because "Knowledge puffeth up..." unlike charity, which "edifieth." ${ }^{84}$ Benjamin Whichcote makes a similar appeal. He worries that zeal for religious truth is really just self-love in disguise, love of "our Fancy," "our 
Religion," "our own Creatures," and "our own Notions." 85 Chillingworth worries that the Catholic dogma of infallibility and the Church's tendency to condemn and exclude those with different theological opinions has the actual affect of encouraging clerical authorities to substitute self-will for honest biblical interpretation. ${ }^{86}$

On the other hand, true Christians are exemplars of tolerance. Whichcote declares:

This I dare undertake is really true of all that are sincere and hearty in their Profession of Religion. And therefore to these there is due, Patience, and Charity. ${ }^{87}$

Dogmatism is ultimately harmful to the piety of others. For Whichcote, serious religious belief entails a tolerant attitude toward differing opinion. This tolerance is resultant from Christian love and is synonymous with "Charity." Chillingworth stresses the importance of tolerant charity in Protestant Christianity. He writes:

And therefore there is no reason but we may believe that their full assurance of the former Doctrine doth very well qualifie their perswasion of the later; and that the former ... are more effectual to temper their hope, and to keep it a stay of a filial and modest assurance of Gods favour, built upon the conscience of his love and fear, than later can be to swell and pff them up into vain confidence and ungrounded presumption. This reason joyn'd with our experience of the honest and religious conversation of many men of this opinion, is a sufficient ground for Charity, to hope well of their Hope: and to assure our selves that it cannot be offensive, but rather most acceptable to God, if, notwithstanding this diversity of opinion, we embrace each other with the strict embraces of love and communion. To you and your Church we leave it, to separate Christians from the Church, and to proscribe them from heaven upon trivial and trifling causes. ${ }^{88}$

By classifying faith with moral probability, Christians with differing views can still be held within the Christian community, not by unity of doctrine, but by the embrace of tolerant charity. In sum, these thinkers' all insist that the disposition of charity, while an end in itself, is instrumental in maintaining religious peace and inclusively. The alternative is religious strife, and the history of seventeenth century conflict shows 
that any boundaries between religious animosity and social discord are fragile and porous.

Ultimately, Locke read or recommended Cambridge-Platonists and the tolerant Anglican divines with clear enthusiasm. Add to that the evident similarities between their thought on charity, and it seems entirely plausible that Locke's conceptualisation was developed in this vein. While certainly of central theological and, consequently, social importance, because this conception of dispositional charity is so closely affiliated with toleration, alternative ways of interpreting the intersection of charity with matters of Lockean political justice can be elucidated.

\section{VI}

Keeping in mind the conceptual closeness of Locke's thought on charity with that of the latitudinarian and Cambridge-Platonist authors examined above, it is evident that he conceives of charity as a disposition equivalent to toleration and fundamental to Christianity. Although requisite under natural law broadly conceived, it is because Locke's charity is a disposition that it is prior to outward human behaviour and, consequently, necessarily absent from that part of natural law included in Lockean political justice. This accounts for Locke's vacillations when discussing charity within the framework of magisterial enforcement, explaining why the obligation of charity to positively benefit mankind, is only enforced negatively when failure to be charitable produces injurious results.

In order to substantiate this claim, some further analysis of the charity in relation to justice and law in Locke's religious and philosophical thought is required, which both allays anxieties about and specifies the grounding of dispositional charity in Lockean politics. In a crucial passage from Of the Conduct of the Understanding, 
Locke remarks that the study and practice of theology are the most important, universal duties. He asserts:

There is indeed, one Science (as they are now distinguished) incomparably above all the rest where it is not corruption narrowed into a trade or faction for meane or ill ends and secular interests, I meane Theolgie, which conteining the knowledge of God and his creatures, our duty to him and our fellow creatures and a view of our present state is the comprehension of all other knowledge directed to its true end i.e. the honour and veneration of the Creator and the happynesse of man kinde. This is that noble study which is every man's duty and one that everyone that can be called a rational creature is capable of. ${ }^{89}$

For Locke, human beings have a normative duty to understand and presumably practice theology. Because he believes charity is the central theological obligation, this passage would seem to indicate that it is not only for aspirant Christians but for all 'rational creatures', all of humanity.

Following Locke's thought on theological duties, it is important to emphasise his belief that just politics always upholds the standards of natural law. ${ }^{90}$ Locke's remarks on the composition of natural law are sparse, but we do know he regularly equated it with God's divine law. Just as in the Gospel where Christ promulgates the duty of charity or neighbourly love to all Christians as the summa and transcendence of Mosaic Law, ${ }^{91}$ Locke applies charity enthusiastically to his conception of divine law. Locke recalls the Gospel of John Chapters 13 - 15, where Christ commands the disciples to love each other as he had loved them. For Locke, this new commandment confirms and purifies the divine moral law, toward which the disciples are obligated. ${ }^{92}$ Because the duty entailed in Locke's other theological writings adduced here is much the same, if there is anything he thinks natural or divine law require it is charity.

If we accept that charity is the essence of the Gospel, Gospel doctrine is the fullness of God's divine law, divine law equals natural law, and that natural law is preserved in government (all of which Locke maintains), then the theological concept 
of charity would seem to be transferred into the sphere of Locke's political thought. But the further claim that charity would be necessity under Lockean political regimes, and anyone who denies it could be punished runs against many of Locke's utterances identified earlier, where acts of charity are morally important but not juridical requirements. There is some perplexity here about the specific relationship between political justice and charity that requires further elaboration.

Taking the dispositional quality of Lockean charity seriously shows the difficulties concerning legally mandatory performances of charitable acts. The point of contradiction emerges when considering what magistrates might legally enforce in regard to charity. Because Locke's charity is higher love, one wonders how such a disposition could be the subject of legal action at all. Certainly a government might command, de jure, that all citizens must bear a charitable disposition in strict accordance with natural law, but it does not require much imagination to see the hollowness of such legislation. Governments can control outward behaviour, they can even impute reasons for actions, but they cannot identify, prevent, or instil dispositions short of a complex educational apparatus absent from Locke's political thought. At best a government might settle for mandating charitable acts.

However, enforcing charitable acts creates a second problem by decisively driving citizens away from charitable dispositions. Expanding on the parallels between charity and Locke's thought on religious toleration helps clarify this. One can force compliance with external acts of worship, but actual doctrinal beliefs are a personal matter not subject to such compulsion. Worse, coercion of charity or acts thereof runs counter to the very non-coercive charity that Locke recommends when dealing with differences of opinion in the Essay. Just as with disagreeing parties attempting to impose orthodoxies on each other, if the magistrate hopes to convince 
someone to be charitable, then forcing them to perform what they should do voluntarily might produce the unintended consequences of contention and spite. Because Locke believes charity is an important universal duty with important civic ramifications, such unnecessary threats to charity should presumably be avoided. Upon this view, Locke's reluctance to make charity part of political justice shows his recognition that legal compulsion cannot command the dispositions and might militate against charity actually flourishing.

Ultimately, the social importance of the disposition of charity requires that acts of charity usually lie outside the remit of Lockean government. A Thomistic interpretation of Lockean charity cannot fit the bill. Nevertheless, all individuals still hold the natural duty to be charitable. So even though this duty is not governmentally actionable, its obligatory status means that the use of charity in Locke's social thought cannot be explained away as mere supererogation. Furthermore, there may be certain cases where Lockean political justice and charity overlap. The identification of such cases relies upon the distinction between positive and negative obligations under natural law. If requiring positive acts of charity is normally illegitimate, it is not true that governments lack authority over anti-charitable behaviour. Hence, people who are acting in clearly uncharitable ways should be restrained. Although it is not clear exactly where the threshold lies between legally permissible exercise of a right to do wrong and actual harm lies, when it is crossed the uncharitable act, as an infraction against negative obligations, becomes criminal. Consequently, Locke appears to permit coercion against such uncharitable behaviour.

Obviously such coercion would apply to such uncharitable acts as highway robbery or murder, but the prohibition of these behaviours is always required under natural law and political justice. The interpretive power of this threshold test is that it 
helps explain juridical action in certain specific cases where a violation of the positive duty to be charitable is at issue. The example from 'Venditio' fits this scenario because, unlike typical criminals, the high prices charged by the corn seller do not necessarily involve an attempt to harm others, only a refusal of positive obligation. Yet we saw above that Locke identifies the case in 'Venditio' as murder. This is because the failure to help is not distinct from the causing of harm. Here the violation of the positive and negative obligation is one and the same. In such cases, the normal distinction between negative and positive obligations dissolves. In these circumstances Charity is perfectly obligatory as part of political justice and prior to other rights save, preservation of self.

Thus, the political role of charity is predicated by Locke's care in distinguishing between charity as a disposition and the grounds of political obligation and prohibition. Nevertheless, Locke takes charity, in this full sense, to be not only central for Christian ethics but also a universal imperative. This view is not narrowly political but suggestive of the systematic tendencies of his broader thought. Without bringing together these various theoretical concerns, Locke would not have seen that political control contravenes the disposition of charity. Justice and charity cannot collapse into each other without endangering the purposes of both. It is for this reason that charity as a disposition of tolerance and beneficence can only ever be a matter of political justice, and therefore only ever trump property rights, in certain tightly defined circumstances. Thus, Locke's work on charity shows both continuance and the negotiation amongst the philosophical, theological, social and political aspects of his thought. It is often the exceptions to the rule that are most revealing.

\footnotetext{
${ }^{1}$ Earlier versions of this paper were presented to: a Graduate Conference at the University of Exeter in May 2005; the Philosophy Department lecture series at St. Francis Xavier University, Nova Scotia in March 2007; and to the Political Studies Association Conference at the University of Bath in April
} 
2007. We are grateful to the audiences, especially Cesare Cuttica, Louis Groarke, Nikola Regent, Tim Stanton, Will Sweet, and Corinna Wagner as well as the three anonymous EJPT referees. We are particularly indebted to Dario Castiglione and Iain Hampsher-Monk for encouragement and insightful criticisms of earlier drafts.

${ }^{2}$ For an account of this, see Paul E. Sigmund, 'Jeremy Waldron and the Religious Turn in Locke Scholarship', The Review of Politics 67: 3 (2005), pp. 407-418

${ }^{3}$ John Dunn, The Political Thought of John Locke: An Historical Account of the 'Two Treatises of Government' (Cambridge, 1969).

${ }^{4}$ Jeremy Waldron, God, Locke, and Equality: Christian Foundations in John Locke's Political Thought (Cambridge, 2002).

${ }^{5}$ C.B. Macpherson, The Political Theory of Possessive Individualism: Hobbes to Locke (Oxford, 1962), p. 221. As Richard Ashcraft points out, Macpherson was not the first to advance this argument. Indeed, such a charge was initially formulated by Marx and Engels in The German Ideology and later approved by a number of figures including George Sabine, Leo Strauss and Harold Laski. See Ashcraft 'The Two Treatises and the Exclusion Crisis: The Problem of Lockean Political Theory as Bourgeois Ideology,' Ashcraft and J.G.A. Pocock (eds) John Locke: Papers read at a Clark Library Seminar (Los Angeles, 1980), p. 27. For critical discussions of Macpherson's interpretation of Locke, see Alan Ryan 'John Locke and the Dictatorship of the Bourgeoisie,' Political Studies 13 (1965), 219-30; James Tully, 'After the Macpherson Thesis,' An Approach to Political Philosophy: Locke in contexts (Cambridge, 1993), pp. 71-95; Iain Hampsher-Monk, 'Evidence and Inference in the History of Political Thought: the case of John Locke's Theory of Property,' Hampsher-Monk and William Twining (eds), Evidence and Inference in History and Law (Evanston, 2003), pp. 329-54.

${ }^{6}$ For a philosophical discussion of the meaning of charity, see Allen Buchanan, 'Justice and Charity,' Ethics 97 (1987): 558-75. See also Jeremy Waldron, 'Welfare and the images of charity,' Liberal Rights: Collected Papers, 1981-1991 (Cambridge, 1993), pp. 225-49.

${ }^{7}$ A. John Simmons, The Lockean Theory of Rights (Princeton, 1992), p. 328.

${ }^{8}$ Discussion of Locke on charity is not uncharted territory. See in particular John Dunn, 'Justice and the Interpretation of Locke's Political Theory,' Political Studies 16 (1968), pp.50-87; James Tully, A discourse on property: John Locke and his adversaries (Cambridge, 1980), pp. 131-35; John C. Winfrey, 'Charity Versus Justice in Locke's Theory of Property,' Journal of the History of Ideas (1981), pp. 423-38; Edward Andrew, Shylock's Rights: A Grammar of Lockian Claims (Toronto, 1988), pp. 53-65; Simmons, Lockean Theory of Rights pp. 307-52; Jeremy Waldron, God, Locke, and Equality, pp. 177-87; Janet Coleman, 'Pre-Modern Property and Self-Ownership Before and After Locke,' European Journal of Political Theory 4 (2005), pp. 125-45. See also Richard Boyd, “The Calvinist Origins of Lockean Political Economy," History of Political Thought, Vol. XXIII, No. 1, (Spring 2002), pp 30 - 60; Boyd suggests that charity's meaning is located within Calvinist economic discourse. The descent of charity from reformation Calvinism, rather than directly from Scholastic natural law, is a crucial corollary of this claim, offering an intriguing alternative to the dominant interpretation. There is substantive and compelling evidence contained here, but Locke's rejection of theological Calvinism raises questions. Boyd is concerned with the religious importance of charity but he does not extend this interest into Locke's substantial religious writings.

${ }^{9}$ Locke, Two Treatises of Government II: §25, p. 286. All references are to Peter Laslett's edition (Cambridge, 1988). Locke's idea of an original community of goods is clearly similar to that of both Grotius and Pufendorf. However, these earlier thinkers conceptualised the community in explicitly negative terms. In other words, the community was one in which individuals begin with only Hohfeldian 'privilege' rights over resources, but can subsequently establish exclusive claim-rights through first occupancy and convention - something Grotius illustrates with Cicero's example of the occupation of seats in a theatre. In the case of Locke, whether or not God's initial bequest of land 'in common' entails negative privileges or positive claim rights is not entirely clear. Jeremy Waldron rejects the negative communist account on the grounds that Locke details a 'primeval claim right' to subsistence, which generates a correlative duty in others, The Right to Private Property (Oxford, 1988) p. 155. Most commentators agree though few give it detailed consideration.

${ }^{10}$ Locke, Two Treatises II: $\$ 27$, pp. 287-88.

${ }^{11}$ Ibid, II: $\S 6$, p. 271.

${ }^{12}$ This, however, is not the whole story. Although labour, as an activity, derives its moral force because it ensures the preservation of individuals, Locke seems also to justify it on the grounds that it creates value (II: $\S \S 40-43$ ). It is not entirely clear whether (or how) the preservation argument and the value argument are connected.

${ }^{13}$ Ibid, II: §34, p. 291. 
${ }^{14}$ Ibid, II: §32, p. 291.

${ }^{15}$ Ibid, II: §34, p. 291.

${ }^{16}$ Ibid, II: $\$ 48$, p. 301.

${ }^{17}$ Ibid, II: $\$ 27$, p. 288.

${ }^{18}$ Robert Nozick, Anarchy, State and Utopia (Oxford, 1974).

${ }^{19}$ Locke, Two Treatises II: $§ 6$, p. 271.

${ }^{20}$ Ibid.

${ }^{21}$ Ibid, II: $\S 159$, p. 375 . See also, II: $\S \S 16,135$.

${ }^{22}$ Ibid, II: $\$ 183$.

${ }^{23}$ Ibid, I: $§ 89$, p. 207.

${ }^{24}$ Ibid.

${ }^{25}$ This emphasis on the moral significance of ability is also prominent in Locke's 'Essay on the Poor Law,' ([1697] Mark Goldie ed. Political Essays (Cambridge, 1997)), which is also frequently cited as evidence of his commitment to a subsistence right. Herein, he identifies the idle poor as a menace, describing them as 'begging drones, who live unnecessarily upon other people's labour' (p. 184). He then goes on to consider the most effective measures to deal with the social problem posed by such 'idle vagabonds'. Notably, Locke's solution is not to ensure a comprehensive subsistence right for the indigent, but rather to punish them. He suggests that 'all men sound of limb and mind' should be 'seized on' and, rather than go to prison - which Locke deems too comfortable a place for them - must instead be deported to a seaport town and forced to undertake 'hard labour', 'lump-breaking' in this case. If the individual in question refuses, they are then transferred to prison. It is true that, at one point in the essay, Locke makes the unequivocal declaration that 'everyone must have meat, drink, clothing, and firing.... whether they work or no[t]' (p. 189). This would seem to be a clear defence of an unconditional subsistence provision. However, such an interpretation does not quite fit. Indeed, Locke's declaration that 'everyone' must be guaranteed such basic necessities is perfectly consistent with his overall plan to punish the idle poor. This is because he clearly believes that these basic requirements of 'meat, drink, clothing, and firing' are clearly satisfied by prisons, which Locke regards as places of relative comfort: 'places of ease and preferment' (p. 185). This, then, is only a subsistence right in the (very) loose sense that any form of (non-capital) punishment entails keeping somebody alive: it clearly represents no significant threat to established property rights.

${ }^{26}$ Locke, Two Treatises, I: $\$ 42$, p. 170.

${ }^{27}$ Smith, Lectures on Jurisprudence. Report of 1762-3, ed. R.L. Meek, D.D. Raphael, P.G. Stein (Oxford, 1978), i. 16, p. 9. Smith describes imperfect rights such as charity as 'those which correspond to those duties which ought to be performed to us by others but which we have no title to compel them to perform'. For a discussion, see Istvan Hont and Michael Ignatieff 'Needs and Justice in the Wealth of Nations,' Hont and Ignatieff (eds) Wealth and Virtue: The Shaping of Political Economy in the Scottish Enlightenment (Cambridge, 1983), p. 24.

${ }^{28}$ Tully, A discourse on property, p. 132. For a thorough discussion of the views of Grotius and Pufendorf on this issue, see John Salter, 'Grotius and Pufendorf on the Right of Necessity,' History of Political Thought XXVI (2) (2005), pp. 284-302.

${ }^{29}$ Tully, A discourse on property, pp. 131-2, emphasis added. As Gopal Sreenivasan points out, however, this is not quite right because at best Locke is defending the rights of the only the 'disabled' poor. The able-bodied poor - as the 'Essay on the Poor Law' shows — do not have a right to charity, but at most a right to employment. Sreenivasan, The Limits of Lockean Rights in Property (Oxford, 1995), pp. 102-104.

${ }^{30}$ Ibid, pp. 64-5, 132. For a comprehensive discussion of Locke's links to the medieval understanding of rights of subsistence, see Scott G. Swanson, 'The Medieval Foundations of John Locke's Theory of Natural Rights: Rights of Subsistence and the Principle of Extreme Necessity,' History of Political Thought XVIII (1997), pp. 399-459.

${ }^{31}$ Aquinas, Summa Theologica II-II, Question 66, Seventh Article. See Aquinas, Political Writings, R.W. Dyson ed. (Cambridge, 2002), p. 216. Aquinas also employs the term 'charity' in the context of this discussion of the acceptability of what would otherwise be regarded as theft, pp. 214-15.

${ }^{32}$ Simmons, Lockean Theory of Rights, p. 328. He also argues that 'given the clarity and directness' of I: 42 'the persistence of the view that Locke denies or is uninterested in rights and duties of charity can only be described as odd' (p. 327). But the important question is not whether Locke is interested in charity, but rather what charity actually means for him and what it entails for his theory of property rights.

${ }^{33}$ Ibid, p. 329. Simmons asks 'if justice is our having what we have a right to, how can rights to charity override or limit the demands of justice? Is charity one kind of justice, in conflict, perhaps, only 
with a lower 'bare justice' (which position would approximate one standard medieval view)? Or is charity a limit to justice, the realm of justice not including all rights (but only, say, negative ones)?' (pp. 328-29). He does maintain, however, that this is only a 'verbal problem'.

${ }^{34}$ Waldron, God, Locke, and Equality, p. 180.

${ }^{35}$ Ibid, p. 181. This does not represent any shift in Waldron's interpretation of Locke. As noted, in The Right to Private Property he rejects a negative communist interpretation of Locke's original community of goods, on the basis that in I: 42 he enshrines a fundamental 'primeval claim-right' over subsistence provisions: 'Locke has, among the foundations of his account, the doctrine that all individuals have a natural right to sustenance and to the use of whatever resources are necessary for their survival' (p. 155).

${ }^{36}$ God, Locke, and Equality, p. 181.

${ }^{37}$ Ibid, p. 185, emphasis suppressed.

${ }^{38}$ Ibid, p. 180.

39 'A right to do wrong,' Liberal Rights: Collected Papers, 1981-1991 (Cambridge, 1993), pp. 63-87.

40 ‘...the Law of Nature stands as an Eternal Rule to all Men'. Locke, II: $§ 135$, pp. 357-58.

${ }^{41}$ Locke, 'An Essay on Toleration,' Political Essays, p. 145.

${ }^{42}$ Locke, 'Venditio', Political Essays, p. 340.

${ }^{43}$ Ibid, p. 341.

${ }^{44}$ Ibid, p. 342.

${ }^{45}$ Locke, Essay, Bk. IV, Chapter 12, § 12 .

${ }^{46}$ Ibid. See Locke's discussion of short-sighted willing in, Bk. II, Chap. 3, § 69; his explanation of the Law of Opinion in Bk. II, Chap. 28, $\S \S 10,12$; his discourse on the barriers against expanding human knowledge Bk. IV, Chap. $3 \S \S 6,20$; and finally Locke's attack against received opinion in Bk. IV, Chap. 20, $\S 17-18$.

${ }^{47}$ Neal Wood, The Politics of Locke's Philosophy, A Social Study of 'An Essay Concerning Human Understanding' (Berkley, 1983). One of Wood's central claims is that Locke's promotion of rationality through education is part of his bourgeois identity. Though this claim is not thoroughly convincing when taking Locke as a philosopher, Wood is completely correct in identifying this trend and the danger of ignorance in Locke's Essay.

${ }^{48}$ Locke, Essay, Bk. IV, Chap. 16, §4.

${ }^{49}$ G. A. J. Rogers, 'Locke and the latitude-men: ignorance as a ground for toleration,' in R. Kroll, R. Ashcraft, and P. Zagorin (eds.), Philosophy, Science, and Religion in England; 1640 - 1700, (Cambridge, 1992), pp. $242-247$. As it happens, this is also the grounds of the dominant interpretation of Locke's argument in his Third Letter on Toleration.

${ }^{50}$ Anthony Wilhelm, 'Good Fences and Good Neighbors: John Locke's Positive Doctrine of Toleration,' Political Research Quarterly, Vol. 52, No. 1, (Mar., 1999), pp. 146 - 148, 152 - 158. Most of Wilhelm's argument is acceptable with the caveat that he overstates the extent of this positivity in so far as the acceptance of differing beliefs is concerned. He seems to believe that Lockean toleration, to put it in contemporary terms, celebrates difference. The discussion of toleration in Locke does not seem indicative of this claim. We would submit that Locke is advancing civil friendship and benevolence in common humanity despite differences. This is a distinction between opinion and opinion bearer that Wilhelm does not seem to develop. This allows the robust positive duty toward toleration and affability, which Wilhelm convincingly argues not to require the further claim that the different opinions are themselves embraced.

${ }^{51}$ This reference is to the Oxford Clarendon edition of the Letter: John Locke, Epistola de TolerantiaA Letter on Toleration, ed. Raymond Klibansky and translated J. W. Gough, Oxford, Oxford Clarendon Press: 1968. This version is translated directly from Locke's original Latin text. Although Locke stood by the more common William Popple translation, it colours Locke's original verbiage. The Popple translation also introduces redundancies into the English absent from the Latin. Critically, there is serious doubt that Locke supervised the Popple translation. For the students of the acceptance and interpretation of Locke, the Popple edition remains crucial source material. See note on William Popple's translation in the Clarendon Letter on Toleration, pp. $43-51$.

${ }^{52}$ Locke, A Letter on Toleration, p. 59.

${ }^{53}$ Ibid. This view pervades the entire first section of the letter. Locke comes back to this same basic point repeatedly. See especially pp. $59-65$.

${ }^{54}$ Locke, The Reasonableness of Christianity, "Preface," Victor Nuovo (ed.) John Locke; Writings on Religion (Oxford, 2002), p. 89.

${ }^{55}$ Ibid, p. 94 . Italics ours.

${ }^{56}$ Ibid, p. 169 
${ }^{57}$ Ibid, pp. 173-174.

${ }^{58}$ Ibid, p. 177.

${ }^{59}$ Holy Bible, I Corinthians 12: $1-2$.

${ }^{60}$ John Locke, Paraphrase of St. Paul's First Letter to the Corinthians, paraphrase I Corinthians 1: 10

-16 .

${ }^{61}$ Ibid, paraphrase I Corinthians 13: 3.

${ }^{62}$ Ibid, paraphrase I Corinthians 12: 31.

${ }^{63}$ John Marshall, 'Locke and Latitudinarianism,' in Kroll, Ashcraft, and Zagorin (eds.), Philosophy, Science, and Religion in England, p. 273.

${ }^{64}$ On the problematic historical grounding for the appellation latitudinarian either as a contemporary term or as some identifiable grouping intellectually distinct thinkers and theologians, see John Spurr, “"Latitudinarianism' and the Restoration Church,” The Historical Journal, Vol. 3, No. 1, (Mar., 1988), pp. 61-82. Spurr concludes that the only really consistent belief amongst thinkers taken to be latitudinarians was their opposition to Calvinist theology and their commitment to charitable and tolerant behaviour toward disagreement. It is not our claim that the latitudinarians are an easily identifiable group who offered a more or less unique view on charity. Rather than submitting claims about Locke's group identification, our position is based upon Locke's identification with individual thinkers and the specifics of their thought on charity.

${ }^{65}$ Sarah Hutton (ed.) 'Intoduction' in Ralph Cudworth, A Treatise Concerning Eternal and Immutable Morality, (Cambridge, 1996), p. xi.

${ }^{66}$ Richard I. Aaron, John Locke, (Oxford, 1953), p. 26. Aaron cites convincingly the Letters with Thomas and Damaris Cudworth and the Clarke correspondence as evidence for this connection.

${ }^{67}$ Marshall, John Locke, p 150 - 151. Marshall argues that Locke's reading of Cudworth is evinced in MS Loke f6 19-20 and 25-32.

${ }^{68}$ John Locke, Selected Correspondence, Mark Goldie (ed.), (Oxford, 2002), Letters 687, 696,699.

${ }^{69}$ Ibid, Letter 1040, p 122.

${ }^{70}$ Ibid, Letter 3328, p. 314.

${ }^{71}$ Maurice Cranston, John Locke, A Biography, (London, 1957), p. 124.

${ }^{72}$ On the correspondence and friendship between Locke and many of the latitudinarians, see Marshall, John Locke, pp. 78-81.

${ }^{73}$ Locke, Selected Correspondence, Letter 3328, p. 314.

${ }_{75}^{74}$ Cranston, John Locke, p. 126.

${ }^{75}$ Locke, 'Some Thoughts Concerning Reading for a Gentleman', BL, MS Sloane 4290, ff. 11 -14, in Locke, Political Essays, M. Goldie (ed.), (Cambridge, 1997).

${ }^{76}$ Marshall, 'Locke and Latitudinarianism,' p. 253. J. Harrison and P. Laslett (eds.) The Library of John Locke, (Oxford, 1965), pp. 119, 192. The books by Cudworth and More feature on these two pages respectively.

77 John Smith, Select Discourses, (Cambridge, W. Morden Booksellers, 1672), Discourse 7, Chap. IV, pp. 300-304. ${ }_{78}^{78}$ Ibid, p. 311.

${ }^{79}$ Alan Gabbey, "Cudworth, More and the mechanical analogy," in Kroll, Ashcraft, and Zagorin (eds.), Philosophy, Science, and Religion in England, pp. 116 - 117.

${ }^{80}$ Passmore, Ralph Cudworth, pp. 55 - 56.

${ }^{81}$ Benjamin Whichcote, Select Sermons, (London, Awnsham and John Churchill, 1698),., Part II, Sermon IV, p. 387.

${ }^{82}$ Ibid, p. 362.

${ }^{83}$ Ibid, p. 380.

${ }^{84}$ Henry More, An Explanation of the Grand Mystery of Godliness, London, 1660, Bk. X, pp. 493 494, cited in Rogers, "Locke and the latitude-men," p. 239.

${ }^{85}$ Whichcote, Select Sermons, Part II, Sermon IV, p. 368.

${ }^{86}$ William Chillingworth, The Religion of Protestants A Safeway to Salvation or, An Answer to a Book Entitled Mercy and Truth, or Charity Maintain'd by Catholiques: Which Pretends to Prove the Contrary, (London, 1674), Chap. II, Par. 3, 28, 130. Robert R. Orr, Reason and Authority, The Thought of William Chillingworth, (Oxford, 1967), pp. 59-60.

${ }^{87}$ Whichcote, Select Sermons, Part II, Sermon IV, p. 367.

${ }^{88}$ William Chillingworth, The Religion of Protestants, Chap. VII, Par. 33

${ }^{89}$ Locke, Of the Conduct of the Understanding, § 34.

${ }^{90}$ See note 39.

${ }^{91}$ Gospel of John, Chapters $13-15$. 
${ }^{92}$ Locke, Reasonableness, pp. [231 - 233], $181-183$. 